\title{
The Board of Directors' Criminal Liability for Companies Which Declared On Bankruptcy
}

\author{
Raditya Triatmaji Pramana*) and Bambang Dwi Baskoro**) \\ *) Faculty of Law, Universitas Diponegoro, email: raditya.triatmaji@gmail.com \\ ${ }^{* *}$ Faculty of Law, Universitas Diponegoro, email: bambangdwibaskoro@lecturer.undip.ac.id
}

\begin{tabular}{|c|c|}
\hline Article & Abstract. \\
\hline $\begin{array}{l}\text { Article History } \\
\text { Received: 2021-10-17; } \\
\text { Reviewed: 2021-11-08; } \\
\text { Accepted: 2021-11-22; } \\
\text { Published: 2021-11-24. } \\
\\
\text { DOI: http://dx.doi.org/1 } \\
\text { 0.30659/jdh.v4i4.17784 }\end{array}$ & $\begin{array}{l}\text { Bankruptcy is regulated in Act No. } 37 \text { of } 2004 \text { concerning Bankruptcy } \\
\text { and Postponement of Debt Payment Obligations (PKPU). In the } \\
\text { regulation, the company is declared bankrupt, meaning that when the } \\
\text { debtor (debt owner) has two or more creditors (debtors) who do not } \\
\text { pay debts that are due and can be collected (cause of bankruptcy). } \\
\text { The responsibility of the Board of Directors whose company is } \\
\text { experiencing bankruptcy is in principle the same as the responsibility } \\
\text { of the Board of Directors whose company is not experiencing } \\
\text { bankruptcy. Bankruptcy status applies when there is a decision of the } \\
\text { Commercial Court, whether it comes from the application itself or } \\
\text { one or more creditors. After being declared bankrupt, the court } \\
\text { decided to sell all of the company's assets, the proceeds of which } \\
\text { were used to pay the debtors' obligations that were already bankrupt } \\
\text { to the creditors. Based on the aforementioned background, a } \\
\text { problem can be drawn as follows: What is the liability of the directors } \\
\text { who are declared bankrupt? How can the board of directors be } \\
\text { declared negligent or wrong which results in the corporation being } \\
\text { declared bankrupt? The approach method used in writing this law is } \\
\text { normative juridical or also called doctrinal law research. The research } \\
\text { specification in this writing is descriptive-analytic. Based on the } \\
\text { results of the research, it can be concluded that the Board of } \\
\text { Directors is not personally responsible for the actions committed for } \\
\text { and on behalf of the Company based on their authority. This is } \\
\text { because the actions of the Board of Directors are seen as actions. The } \\
\text { Board of Directors is said to have been wrong or negligent which } \\
\text { resulted in the Company being declared bankrupt, namely the lack of } \\
\text { good faith by the directors to pay off debts to creditors. The Board of } \\
\text { Directors neglected to pay off debts to creditors. }\end{array}$ \\
\hline
\end{tabular}

(C)2021; This is an Open Access Research distributed under the term of the Creative Commons Attribution License (https://Creativecommons.org/licences/by/4.0), which permits unrestricted use, distribution, and reproduction in any medium, provided the original works is properly cited

\section{Introduction}

Asset management during bankruptcy is carried out by a curator appointed by the court. In other words, only the Commercial Court can decide whether a company is bankrupt or not. To be able to bankrupt a business entity, there are conditions that must be met, especially regarding obligations that cannot be paid at maturity. Along with the development of the business world, various parties conduct a more comprehensive study of the business world, both from a practical point of view as well 
as theoretical thinking. The emergence of ideas both in theory and practice must be done at this time, because when it comes to running a business, there are almost no boundaries between countries. This is because in the development of the business world, crossing between countries is very fast. ${ }^{1}$ Therefore, regardless of the legal norms or characteristics of the company that will conduct business activities, those who wish to carry out their business activities abroad must understand the legal provisions in force in that country, especially those relating to the Company's business entities. $^{2}$

The company is the most preferred form of economic activity at this time, in addition to its limited liability, the company also makes it easy for the owner or shareholders to transfer the company to anyone by selling all the shares they own in the company. The presence of the Company is one of the business vehicles that contributes to almost all areas of human life. ${ }^{3}$ The company has created jobs, improved the welfare of the community, and made significant contributions to economic and social development. In principle, the Company as a legal entity can have all the rights and obligations that can be owned by everyone. In order to carry out all the rights and obligations it has, legal science has formulated the functions and duties of each organ of the Company which differ from one another. These organs are known as the General Meeting of Shareholders, the Board of Commissioners, and the Board of Directors. ${ }^{4}$

The Board of Directors is entrusted by all shareholders through the mechanism of the General Meeting of Shareholders to become the Company's Organ that will work for the benefit of the Company, as well as the interests of all shareholders who appoint and entrust it as the only Organ that manages and manages the Company. ${ }^{5}$ The existence of the Board of Directors in a company is a must, or in other words the company must have a board of directors, because the company as an artificial person cannot do anything without the assistance of the board of directors as a natural person. Therefore, the existence of the Board of Directors for the Company is very important. Even though the Company is a legal entity, which has separate assets from the Board of Directors, it is only based on legal fiction, that the Company is considered as a legal subject, just like humans.

The Board of Directors is fully responsible for the management and operation of the Company for the interests and objectives of the Company. In carrying out their duties, the Board of Directors is given full rights and powers, with the consequence that every action and action taken by the Board of Directors is given full rights and

\footnotetext{
1 Sri Redjeki Hartono. 1995. Perspektif Hukum Bisnis Pada Era Teknologi (Semarang: Badan Penerbit Universitas Diponegoro. p. 3.

${ }^{2}$ Sri Edi Swasono. 2008. Tentang Demokrasi Ekonomi Indonesia. Jakarta: Bappenas. p. 57.

${ }^{3}$ Sri Redjeki Hartono. 'Tanggung Jawab Sosial Perusahaan Suatu Kajian Komprehensif'. Jurnal Legislasi Indonesia. 6.2 (2009), 53-64.p.58.

4 Amiek Soemarmi Siti Malikhatun Badriyah and Kornelius Benuf Siti Mahmudah, Etty Susilowati, Yunanto. 'The CV as an Initiative for Sustainable Development of Small-Scale Capture Fisheries in Central Java, Indonesia', International Journal of Criminology and Sociology, 10.1 (2021), 249-253.p.252.

${ }^{5}$ Kornelius Benuf Nur Adhim, Siti Mahmudah. 'Telaah Yuridis Terhadap Surat Edaran Kementrian Agraria Dan Tata Ruang NO. 2/SE-HT. 02.01/VI/2019'. Jurnal Hukum Dan Pembangunan, 50.3 (2021), 661675.p.668.
} 
power, with the consequence that every action and action taken by the Board of Directors will be considered and required as the actions and actions of the Company as long as they act in accordance with what is specified in the Company's Articles of Association. ${ }^{6}$ If the actions of the Board of Directors are detrimental to the Company, which are carried out outside the limits of authority given to them by the Articles of Association, it means that the Directors are personally responsible for their actions outside the limits of authority given in the Articles of Association of the Company. ${ }^{7}$

In carrying out the management of the Company, the Board of Directors is not only responsible for the Company, but also for third parties who have legal relations with the Company, either directly or indirectly with the Company. Therefore, a member of the Board of Directors must act carefully in carrying out his duties (duty of care). In addition, in carrying out his duties, a Board of Directors may not take advantage of himself for the company (duty of loyalty). Violation of these two principles in relation to fiduciary duty can cause the Board of Directors to be held personally responsible for their actions, both to shareholders and to other parties.

Fiduciary Duty of a Board of Directors is a duty that legally (by the operation of law) of a fiduciary relationship between the Board of Directors and the company he leads, causes the Board of Directors to act as a trustee in the legal sense of trust, so that a Board of Directors must have the care and ability (duty of care and ability), good faith, loyalty and honesty to the company with a high degree. Violation of fiduciary duty, as well as other legal violations, entitles the injured party to and on his behalf to file a lawsuit against the party who issued the loss. ${ }^{8}$ Whether or not there has been a violation of fiduciary duty by the Board of Directors in using the business judgment rule.

The occurrence of Bankruptcy within the Company, resulted in that the Board of Directors is no longer entitled and authorized to manage the assets of the Company, as a Legal Entity established with the intent and purpose to run the company. Bankruptcy may result in the Company no longer being able to carry out its business activities. If the Company does not carry out business activities, of course it will cause losses, not only for the Company itself, but also for the interests of the Company's shareholders, not to mention the interests of creditors who cannot be paid in full from the sale of all of the Company's assets. ${ }^{9}$

Based on the above background, the formulation of the problem in this study is: How is the criminal responsibility of the board of directors against a company declared bankrupt? How can the board of directors be declared negligent or wrong which resulted in the company being declared bankrupt?

Prior to this study, there were several studies examining the criminal liability of

\footnotetext{
${ }^{6}$ Nur Aisyah Kustiani Moh. Luthfi Mahrus, Muhadi Prabowo. 'Analisis Pencatatan Piutang Subrogasi Pada Perusahaan Penjaminan'. Jurnal Riset Terapan Akuntansi, 4.1 (2020), 31-45.p.37.

7 Asrul Sani. 'Tinjauan Hukum Mengenai Praktik Pemberian Jaminan Pribadi Dan Jaminan Perusahaan'. Jurnal Hukum \& Pembangunan, 23.3 (2017), 426-443.p.429.

${ }^{8}$ Herun Inayah. 'Pelaksanaan Penyelesaian Klaim Dan Subrogasi Atas Klaim Yanh Telah Dibayarkan Oleh Perusahaan Surety Dalam Perjanjian Surety Bond Di PT Jasaraharja Putera Cabang Mataram'. Jurnal Law Reform, 12.2 (2017), 23-43. p. 36.

${ }_{9}^{9}$ Alexander Harsono. 'Understanding E-Business \& E-Commerce And Their Relation To The Conceptual Framework Of Emarketing: Case Study'. Jurnal Informatika Dan Komputer, 2.1 (2011), 50-64.p.53.
} 
directors to companies. In 2017, Veina Yuwono Setianto researched about In principle the Board of Directors is not personally responsible for the actions taken for and on behalf of the Company based on the authority it has. This is because the actions of the Board of Directors are seen as the actions of the Company which is an independent legal subject so that the Company is responsible for the actions of the Company itself which in this case is represented by the Board of Directors. ${ }^{10}$

In 2018, M. Faisal Rahendra Lubis researched on the Responsibility of the Board of Directors when Bankruptcy Occurred in the Company According to the provisions of Act No. 40 of 2007, it is in the event that bankruptcy occurs due to the fault or negligence of the Board of Directors and the assets of the bankrupt are not sufficient to pay all of the Company's obligations in bankruptcy. Accordingly, each member of the Board of Directors is jointly and severally responsible for all outstanding obligations of the bankruptcy estate; otherwise members of the board of directors are not responsible for the bankruptcy of the Company as referred to in paragraph (2). ${ }^{11}$

In 2017, Erna Widjajati researched that the Board of Directors is not personally responsible for actions taken for and on behalf of the Company based on the authority they have. This is because the actions of the Board of Directors are seen as the actions of the Company which are independent legal subjects so that the Company is responsible for the actions of the Company itself which are presented by the Board of Directors. However, the Board of Directors may also be held personally responsible. Based on Article 104 paragraph (2) of Act No. 40 of 2007 concerning Limited Liability Companies, a member of the Board of Directors can be held legally responsible when the Company goes bankrupt for his fault or negligence in managing the Company. ${ }^{12}$ Based on the previous studies described above, what distinguishes this research from that research is that this study examines the application of Article 359 of the Criminal Code (regarding negligence) relating to the responsibility of the captain for ship accidents at sea. So that this research has novelty in overcoming the responsibility of the captain for ship accidents at sea.

\section{Research Methods}

This research uses a normative juridical method or normative law. ${ }^{13}$ This study uses a library approach where the method or method used in legal research is carried out by examining existing library materials. The specifications in the research used are Analytical Descriptive ${ }^{14}$ relating to aspects concerning the criminal liability of the board of directors against companies declared bankrupt. In general, the types of data

\footnotetext{
10 Verina Yuwono Setianto. 2017. 'Pertanggungjawaban Pribadi Direksi pada Perseroan Terbatas Yang Pailit' . Universitas Airlangga..p. 3.

${ }^{11}$ M. Faisal Rahendra Lubis. 'Pertanggungjawaban Direksi Disuatu Perseroan Terbatas Ketika Terjadi Kepailitan Pada Umumnya Dan Menurut Doktrin Hukum Perusahaan \& Undang-Undang No. 40 Tahun 2007". Jurnal Hukum Kaidah, 3.2 (2018), 34-54. p. 34.

12 Erna Widjajati. 2017. "Tanggung Jawab Direksi Perseroan Terbatas Yang Dinyatakan Pailit". Universitas Krisnadwipayana Jakarta. .p. 7.

${ }^{13}$ Depri Liber Sonata. 'Metode Penelitian Hukum Normatif Dan Empiris Karakteristik Khas Dari Metode Meneliti Hukum'. Fiat Justisia Jurnal Ilmu Hukum, 8.1 (2014), 15-35.p.23.

14 Zainal Askin Amirudin. 2012. Pengantar Metode Penelitian Hukum. Jakarta: Raja Grafindo Persada. p.45.
} 
required in a legal research are focused on secondary data research, including: the 1945 Constitution, the Criminal Code, the Criminal Code, Act No. 40 of 2007 concerning Limited Liability Companies.

\section{Result and Discussion}

\subsection{The Board of Directors' Criminal Liability for Companies Declared Bankrupt}

The corporate criminal liability policy in legal consumer protection efforts has not been specifically regulated. The Consumer Protection Act which is specifically made to protect the interests of consumers is the legal umbrella for consumers in Indonesia. In general, the current laws and regulations relating to consumer protection have not specifically regulated criminal liability for corporations. ${ }^{15}$ The law only regulates criminal liability to its management, not to corporations.

Bankruptcy is a process in which a debtor who has financial difficulties to pay his debts is declared bankrupt by the Court, in this case the Commercial Court, because the debtor cannot pay his debts. ${ }^{16}$ According to Soemantri Hartono, bankruptcy is a European civil law institution as a realization of the two main principles in European civil law as stated in articles 1131 and 1132 of the Civil Code. ${ }^{17}$

The main purpose of bankruptcy is to make the distribution between the creditors of the debtor's assets by the Curator. Bankruptcy is intended to avoid separate confiscation or separate execution by creditors and replace it by holding joint confiscations so that the debtor's assets can be distributed to all creditors in accordance with their respective rights. Bankruptcy institutions are basically an institution that provides a solution to the parties if the debtor is in a state of stopping/unable to pay.

Responsibilities of the Board of Directors in a company declared bankrupt. As has been explained, the Company's organs consist of the General Meeting of Shareholders (GMS), Commissioners and Directors. These three organs have different duties, authorities, and responsibilities. The Board of Directors is one of the organs of the Company which has the duty and is fully responsible for the management of the Company for the benefit of the Company's objectives and represents the Company both inside and outside the court in accordance with the provisions contained in the Articles of Association. ${ }^{18}$

The Board of Directors has a very central function and role in the Company's paradigm. This is because the Board of Directors will carry out the management and representative functions of the Company. ${ }^{19}$ The Board of Directors is a Company organ that is authorized and fully responsible for managing the Company for the benefit of the Company, in accordance with the purposes and objectives of the Company and

\footnotetext{
${ }^{15}$ Setiyono. 2005. Kejahatan Korporasi . Malang: Banyumedia Publishing. p.78.

${ }^{16}$ Elyta Ras Ginting. 2018. Hukum Kepailitan: Teori Kepailitan. Jakarta: Bumi Aksara. p. 80.

${ }^{17}$ Reka Aditya Nugraha. 'Analisis Yuridis Perlindungan Hukum Bagi Pemberi Jaminan (Surety) Dan Oblige Terhadap Principal Yang Dinyatakan Pailit'. Jurnal Law Review, 17.2 (2017), 12-21.p.17.

18 Setianto. Op cit. p.37.

19 M. Sampul. 'Tanggung Jawab Bank Terhadap Hak Yang Dirugikan Dalam Pembobolan Rekening Nasabah Menurut Undang-Undang Nomor 10 Tahun 1998 Tentang Perbankan'. Lex Crimen, 5.7 (2016), 125-132.p.129.
} 
representing the Company, both inside and outside the court in accordance with the provisions contained in the Articles of Association.

According to the Organism theory of Otto von Gierke as quoted by Syuiling, "Directors are organs or equipment of legal entities. Just as humans have organs, such as hands, feet, eyes, ears and so on and because every movement of these organs is desired or ordered by the human brain, every movement or activity of the Board of Directors of a legal entity is desired or ordered by the legal entity itself, so that The Board of Directors is the personification of the legal entity itself. On the other hand, Paul Scholten and Bregstein (1954), immediately stated that the Board of Directors represents a legal entity. ${ }^{20}$

The responsibilities of the Board of Directors whose company is bankrupt are, in principle, the same as the responsibilities of the Board of Directors whose company is not bankrupt. Further regulation of the responsibilities of the Board of Directors can be seen from certain conditions. In principle, the Board of Directors is not personally responsible for actions taken on behalf of the Company which are carried out based on the authority they have. This is because the actions of the Board of Directors are seen as the actions of the Company which are legal subjects. However, there are some things that the Board of Directors can be held personally responsible for in the bankruptcy of the Company. ${ }^{21}$

Based on Article 104 paragraph (2) of the Company Law, it states that "In the event of bankruptcy as referred to in paragraph (1) there is an error or negligence of the Board of Directors and the Bankruptcy's assets are not sufficient to pay all of the Company's obligations in the bankruptcy. Each member of the Board of Directors is jointly and severally responsible for all outstanding obligations from the Bankruptcy assets". In addition, Article 104 paragraph (4) states: "Members of the Board of Directors are not responsible for the bankruptcy of the Company as referred to in paragraph (2) if they can prove; ${ }^{22}$ the bankruptcy is not due to his fault or negligence, has managed in good faith, prudence, and full responsibility for the interests of the Company in accordance with the purposes and objectives of the Company, has no conflict of interest either directly or indirectly over the management actions taken, has taken action to prevent bankruptcy.

However, it is not an easy thing to prove that the Board of Directors has made mistakes and/or omissions that have caused a company to go bankrupt which led to bankruptcy. From this arrangement, there is actually a common thread between the responsibilities of the Board of Directors of the Company not in Bankruptcy and the responsibility of the Board of Directors in the event that the Company experiences Bankruptcy. Thus, the various theories of the responsibility of the Board of Directors above can also be used to measure the responsibility of the Board of Directors in the event that the Company goes into bankruptcy. Meanwhile, Article 104 paragraph (2) of

\footnotetext{
${ }^{20}$ Siti Malikhatun Badriyah. 'Pemuliaan (Breeding) Asas-Asas Hukum Perjanjian Dalam Perjanjian Leasing Di Indonesia'. Yustisia, 1.2 (2012), 47-62.p.52.

${ }^{21}$ Munir Fuady. 2003. Arbitrase Nasional (Alternatif Penyelesaian Sengketa Bisnis) (Bandung: PT. Citra Aditya Bakti. p.28.

22 Munir Fuady. 2011. Pengantar Hukum Bisnis: Menata Hukum Bisnis Modern Di Era Global . Jakarta: Citra Aditya Bakti. p.23.
} 
the Company Law is a juridical implication of the collegiality nature of the Board of Directors in which all members of the Board of Directors are jointly and severely responsible so that for members of the Board of Directors who wish to discharge the joint and several responsibilities, the member of the Board of Directors is obliged to prove regarding that matter.

\subsection{Directors Can Be Declared Negligent Or Wrong Which Results In The Company Being Declared Bankrupt}

If someone is harmed because of someone else's actions, while between them there is no agreement (a legal relationship of agreement), then based on the law there is also a legal relationship between the person that causes the loss. This is regulated in Article 1365 of the Civil Code, as follows:

"Every act that violates the law that causes harm to another person obliges the person who because of his fault published the loss, compensates for the loss"

According to Article 1365 of the Civil Code, what is meant by an unlawful act is an unlawful act committed by a person who because of his fault has caused harm to another person. In law, there are 3 (three) categories of unlawful acts, namely as follows; Acts against the law due to intentional, acts against the law without error (without an element of intent or negligence and Acts against the law due to negligence). ${ }^{23}$ Liability for unlawful acts can be intentional and unintentional or due to negligence. If a company goes bankrupt, then suddenly (not by law) the board of directors must be personally responsible, so that the members of the board of directors can be asked for personal responsibility when a company goes bankrupt must meet all of the following requirements; ${ }^{24}$ there is an element of error (intentional) or negligence on the part of the board of directors (with ordinary evidence), to pay debts and bankruptcy costs, must first be taken from the assets of the Company. If the Company's assets are insufficient, then the personal directors' assets are taken, reverse proof is applied for members of the board of directors who can prove that the Company's bankruptcy was not due to error (intentional) or negligence.

In carrying out their duties to manage the Company, the board of directors may not receive benefits for themselves. This means that the interests of the Company must come first. The responsibility for managing the company that is imposed on the board of directors cannot be carried out by the board of directors themselves. ${ }^{25}$ In many cases the entire work of the board of directors is delegated to its employees on the basis of the power of attorney from the board of directors. This means that there is no way for employees without the board of directors and it is impossible for the board of directors to carry out their duties without employees. Therefore, the directors and

\footnotetext{
${ }^{23}$ Kornelius Benuf, Siti Mahmudah, and Ery Agus Priyono. 'Perlindungan Hukum Terhadap Keamanan Data Konsumen Financial Technology Di Indonesia'. Refleksi Hukum: Jurnal IImu Hukum, 3.2 (2019), 145160.p.152.<https://doi.org/10.24246/jrh.2019.v3.i2.p145-160>.

${ }^{24}$ Ira Alia Maerani Junaidi, Sri Endah Wahyuningsih. 'Responsibilities Of The Corporate Director Against The Dark Criminal Action In The Position Based On The Decision Of The Court Sumber Of Cirebon Regency (Studies on Decision No.202 / Pid.B / 2019 / PN.Sbr)'. Jurnal Daulat Hukum, 3.1 (2020), 4148.p.43.

25 Kornelius Benuf Iqbal Satrio Putra, Budi Santoso. 'Online Dispute Resolution Sebagai Alternatif Penyelesaian Sengketa Bisnis Financial Technology Di Indonesia'. Simbur Cahaya, 27.2 (2021), 1-22. p.5.
} 
employees have a fiduciary relationship, which requires one another.

In the PT theory regarding the obligations of the Company's directors, the opinion is that the Company's directors have 2 (two) kinds of obligations, namely obligations based on statutory duties and obligations based on fiduciary duties. In carrying out the management and representation of the Company, the board of directors must act carefully, properly or as well as possible in accordance with the authority given in the articles of association. If in the management and representation of the Company, the Board of Directors commits an act or action that violates the limits of authority or a provision that has been stipulated in the articles of association, the third party may be held personally responsible for him, either individually or jointly for the whole. The company is not responsible for the actions of the board of directors that exceed the authority given to him by the articles of association. Losses suffered by third parties are not the responsibility of the Company, but are the personal responsibility of the entire board of directors.

With regard to the existence of bankruptcy claims against the Company, in practice there are many decisions stating that bankruptcy claims cannot be granted due to an element of negligence committed by the Company's board of directors so that the directors in their position as individuals are jointly and severally responsible. The reasons for the negligence committed by the board of directors include the absence of approval from the board of commissioners as specified in the articles of association. Personal liability if due to the negligence of the board of directors the company becomes bankrupt is that a former member of the board of directors whose company is bankrupt is considered as if the bankruptcy is bankruptcy against himself so that the existence of bankruptcy makes his rights limited. ${ }^{26}$

So, the directors are said to be wrong or negligent which resulted in the company being declared bankrupt, namely the lack of good faith by the directors to pay off debts to creditors. The Board of Directors failed to pay debts to creditors. So, it is known that the board of directors is not said to be negligent or wrong which resulted in bankruptcy as long as the directors have good intentions with reference to duty care and carry out management according to the authority given to them. However, if it is proven otherwise resulting in the bankruptcy of the Company, the board of directors may be held jointly and severally liable through the bankruptcy process in the Commercial Court. This is done so that the fulfilment of payment of creditors' receivables can be carried out in a fair and balanced manner.

\section{Conclusion}

The actions of the Board of Directors are seen as the actions of the company which is an independent legal subject so that the company is responsible for the actions of the company itself which are presented by the Board of Directors. However, the Board of Directors may also be held personally responsible. Based on Article 104 paragraph (2) of Act No. 40 of 2007 concerning Limited Liability Companies, a member of the Board of Directors can be held legally responsible when the company goes

\footnotetext{
${ }^{26}$ Mariske Myeke Tampi. 'Menakar Progresivitas Teknologi Finansial (Fintech) Dalam Hukum Bisnis Di Indonesia'. Era Hukum Jurnal Ilmiah Hukum, 16.2 (2016), 246-281.p.251.
} 
bankrupt as a mistake or negligence in managing the company. The Board of Directors is said to be wrong or negligent which resulted in the Company being declared bankrupt, namely the lack of good faith by the Board of Directors to pay off debts to creditors. The Board of Directors failed to pay debts to creditors. So it is known that the board of directors is not said to be negligent or wrong which resulted in bankruptcy as long as the directors have good intentions with reference to duty care and carry out management according to the authority given to them. The interpretation of good faith which is the benchmark for the errors and omissions of the board of directors, because the Company Law does not provide an interpretation, it is submitted for further development by the court and the existing doctrines.

\section{References}

\section{Journals:}

[1] Badriyah, Siti Malikhatun. 'Pemuliaan (Breeding) Asas-Asas Hukum Perjanjian Dalam Perjanjian Leasing Di Indonesia'. Yustisia, 1.2 (2012), 47-62

[2] Benuf, Kornelius, Siti Mahmudah, and Ery Agus Priyono. 'Perlindungan Hukum Terhadap Keamanan Data Konsumen Financial Technology Di Indonesia'. Refleksi Hukum: Jurnal IImu Hukum, 3.2 (2019), 145-160 <https://doi.org/10.24246/jrh.2019.v3.i2.p145-160>

[3] Depri Liber Sonata. 'Metode Penelitian Hukum Normatif Dan Empiris Karakteristik Khas Dari Metode Meneliti Hukum'. Fiat Justisia Jurnal IImu Hukum, 8.1 (2014), 15-35

[4] Harsono, Alexander. 'Understanding E-Business \& E-Commerce And Their Relation To The Conceptual Framework Of Emarketing: Case Study'. Jurnal Informatika Dan Komputer, 2.1 (2011), 50-64

[5] Hartono, Sri Redjeki. 'Tanggung Jawab Sosial Perusahaan Suatu Kajian Komprehensif', Jurnal Legislasi Indonesia, 6.2 (2009), 53-64

[6] Inayah, Herun. 'Pelaksanaan Penyelesaian Klaim Dan Subrogasi Atas Klaim Yanh Telah Dibayarkan Oleh Perusahaan Surety Dalam Perjanjian Surety Bond Di PT Jasaraharja Putera Cabang Mataram', Jurnal Law Reform, 12.2 (2017), 23-43

[7] Iqbal Satrio Putra, Budi Santoso, Kornelius Benuf. 'Online Dispute Resolution Sebagai Alternatif Penyelesaian Sengketa Bisnis Financial Technology Di Indonesia'. Simbur Cahaya, 27.2 (2021), 1-22

[8] Junaidi, Sri Endah Wahyuningsih, Ira Alia Maerani. 'Responsibilities Of The Corporate Director Against The Dark Criminal Action In The Position Based On The Decision Of The Court Sumber Of Cirebon Regency (Studies on Decision No.202 / Pid.B / 2019 / PN.Sbr)', Jurnal Daulat Hukum. 3.1 (2020), 41-48

[9] Lubis, M. Faisal Rahendra. 'Pertanggungjawaban Direksi Disuatu Perseroan Terbatas Ketika Terjadi Kepailitan Pada Umumnya Dan Menurut Doktrin Hukum Perusahaan \& Undang-Undang No. 40 Tahun 2007'. Jurnal Hukum Kaidah, 3.2 (2018), 34-54

[10] Moh. Luthfi Mahrus, Muhadi Prabowo, Nur Aisyah Kustiani. 'Analisis Pencatatan Piutang Subrogasi Pada Perusahaan Penjaminan'. Jurnal Riset Terapan Akuntansi, 4.1 (2020), 3145

[11] Nugraha, Reka Aditya. 'Analisis Yuridis Perlindungan Hukum Bagi Pemberi Jaminan (Surety) Dan Oblige Terhadap Principal Yang Dinyatakan Pailit'. Jurnal Law Review, 17.2 (2017), 12-21

[12] Nur Adhim, Siti Mahmudah, Kornelius Benuf. 'Telaah Yuridis Terhadap Surat Edaran Kementrian Agraria Dan Tata Ruang NO. 2/SE-HT. 02.01/VI/2019'. Jurnal Hukum Dan Pembangunan, 50.3 (2021), 661-675

[13] Sampul, M. 'Tanggung Jawab Bank Terhadap Hak Yang Dirugikan Dalam Pembobolan 
Rekening Nasabah Menurut Undang-Undang Nomor 10 Tahun 1998 Tentang Perbankan'. Lex Crimen, 5.7 (2016), 125-132

[14] Sani, Asrul. 'Tinjauan Hukum Mengenai Praktik Pemberian Jaminan Pribadi Dan Jaminan Perusahaan'. Jurnal Hukum \& Pembangunan, 23.3 (2017), 426-443

[15] Siti Malikhatun Badriyah and Kornelius Benuf Siti Mahmudah, Etty Susilowati, Yunanto, Amiek Soemarmi. 'The CV as an Initiative for Sustainable Development of Small-Scale Capture Fisheries in Central Java, Indonesia'. International Journal of Criminology and Sociology, 10.1 (2021), 249-253

[16] Tampi, Mariske Myeke. 'Menakar Progresivitas Teknologi Finansial (Fintech) Dalam Hukum Bisnis Di Indonesia'. Era Hukum Jurnal Ilmiah Hukum, 16.2 (2016), 246-281

\section{Books:}

[1] Amirudin, Zainal Askin. 2012. Pengantar Metode Penelitian Hukum. Jakarta: Raja Grafindo Persada

[2] Ginting, Elyta Ras. 2018. Hukum Kepailitan: Teori Kepailitan. Jakarta: Bumi Aksara

[3] Hartono, Sri Redjeki. 1995. Perspektif Hukum Bisnis Pada Era Teknologi. Semarang: Badan Penerbit Universitas Diponegoro.

[4] Munir Fuady. 2003. Arbitrase Nasional (Alternatif Penyelesaian Sengketa Bisnis). Bandung: PT. Citra Aditya Bakti.

[5] - - . 2002. Doktrin-Doktrin Modern Dalam Corporate Law Dan Eksistensinya Dalam Hukum Indonesia. Bandung: Citra Aditya Bakti.

[6] 2011. Pengantar Hukum Bisnis: Menata Hukum Bisnis Modern Di Era Global. Jakarta: Citra Aditya Bakti.

[7] Setianto, Verina Yuwono. 2017. 'Pertanggungjawaban Pribadi Direksipada Perseroan Terbatas Yang Pailit' . Universitas Airlangga.

[8] Setiyono. 2005. Kejahatan Korporasi. Malang: Banyumedia Publishing

[9] Swasono, Sri Edi. 2008. Tentang Demokrasi Ekonomi Indonesia. Jakarta: Bappenas.

[10] Widjajati, Erna. 2017. 'Tanggung Jawab Direksi Perseroan Terbatas Yang Dinyatakan Pailit'. Universitas Krisnadwipayana Jakarta.

\section{Regulation:}

[1] Act No. 37 of 2004 concerning Bankruptcy and Postponement of Debt Payment Obligations (PKPU)

[2] Act No. 40 of 2007 concerning Limited Liability Companies 